\title{
Successful Learning of Academic Word List via MALL: Mobile Assisted Language Learning
}

\author{
Minoo Alemi ${ }^{1}$, Mohammad Reza Anani Sarab ${ }^{2}$ \& Zahra Lari ${ }^{1}$ \\ ${ }^{1}$ Sharif University of Technology, Tehran, Iran \\ ${ }^{2}$ Shahid Beheshti University, Tehran, Iran \\ Correspondence: Minoo Alemi, Languages and Linguistics Department, Sharif University of Technology, \\ Tehran 11155, Iran. Tel: 98-216-616-4812. E-mail: alemi@sharif.ir
}

Received: June 27, 2012 Accepted: July 16, 2012 Online Published: September 26, 2012

doi:10.5539/ies.v5n6p99 URL: http://dx.doi.org/10.5539/ies.v5n6p99

\begin{abstract}
Mobile phones as new addition to information and communication technologies have created new ways to help learners in the process of foreign language learning. Given the importance of academic vocabularies for university students, this study tried to investigate the effectiveness of SMS on Iranian university students' vocabulary learning and retention. To this end forty five university freshman students with upper intermediate proficiency level were chosen to take part in this study. During 16 weeks of experiment, the participants of the experimental group ( $\mathrm{N}=28)$ were taught 320 head words from the Academic Word List (Coxhead, 2000) via SMS. During the same period of time the participants of the control group $(\mathrm{N}=17)$ were taught the same words by using dictionary. At the end, both groups were given a vocabulary test from Academic Word List, to see the effect of SMS on their vocabulary learning and the scores of each group were compared employing an independent t-test. The result of the t-test showed that both groups had improved in the post-test. Although there was not any significant difference between the groups in the post-test, the result of the delayed post-test showed that SMS had more significant effect on vocabulary retention compared to using dictionary, and the experimental group outperformed the control group. The result of this study can have pedagogical implication for language teachers, in that they can use SMS as a useful way to help their students to retain vocabularies in their long-term memory.
\end{abstract}

Keywords: MALL, vocabulary retention, academic word list

\section{Introduction and Literature Review}

Learning new vocabulary is an integral part of learning a new language. Some researchers estimated that in order to understand nontechnical English texts, learners should know at least 5000 lexical items (Laufer, 1998; Nation, 2006). Because of the limited class hours, students do not have the opportunity to speak and use all of the words in class. This causes some problems for language teachers and learners. The problem faced a language teacher is how to teach this large number of vocabulary during the limited time of the class. They can focus and teach individual words explicitly, but deliberately teaching of vocabulary is one of the least efficient ways of developing learners' vocabulary knowledge. However, explicitly teaching of vocabulary constitutes an integral part of a well balanced vocabulary program (Nation, 2001). The problem that learners face when exposed to explicit teaching of vocabulary is the difficulty of the language learning process. They should memorize and learn the large amount of words of the language they are learning. This urges Language teachers and researchers to look for alternative ways to traditional classroom teaching of vocabulary and to change vocabulary learning into a lifelong process which would exceed the limits of the classroom and would be adapted to the needs of learners. They attempt to make learning interesting for students and make them more responsible for their own learning.

One of the ways that can help teachers in teaching vocabulary is using different technologies available to students. Cognitive and sociocognitive approaches have the implication of how to integrate technology into teaching communicatively. Cognitive psychologists see language learning as a psychological process through which learners construct a mental model of the language system based on the interaction of cognitive knowledge and comprehensible input. Some of the technologies that are the focus of cognitive approaches include text-reconstruction software, concordancing software, telecommunications, and multimedia simulation software (Warschauer\& Meskill, 2000).Sociocognitive approaches view language learning as a process of socialization 
into a particular discourse community. In these approaches, learners should have the opportunity to have interaction in an authentic social context in order to have access to comprehensible input and practice language in contexts which would engage them in real life communication (Warschauer \& Meskill, 2000). Internet provides the technological platform required by this approach.

One of the technological advances of the modern age is mobile phone which has dominated most students' lives. It is not just a communication device any more. It is a useful computer that fits into students' pockets, is always with them and nearly always on, and can be used in any kind of learning (Prensky, 2005). Mobile phone, as a new technology, has brought about a new type of language learning called Mobile Assisted Language Learning.

The advent of any method of teaching language has always been accompanied by the use of different technologies (Salaberry, 2001). In other words, any act of teaching necessitates using a kind of technology (Warschauer \& Meskill, 2000). Mobile assisted language learning is a teaching method which uses the mobile phone technology as a way of stressing learner centeredness and autonomy. Based on the different definitions provided for mobile learning, it is employing different technologies that makes m-learning different from other kinds of learning (O'Malley, C., Vavoula, G., Glew, J., Taylor, J., Sharples, M., \& Lefrere, P., 2003). According to O'Malley et al.(2003) mobile learning includes any kind of learning that takes place when the learner is not in a fixed state and he/she takes advantage of mobile technology. Generally, according to Geddes (2004) it is the kind of learning which takes place at any time and in any place, that is; it extends teaching and learning outside of the walls of the classroom. An important feature of this type of learning is that students feel responsible for their own learning.

One of the most used features of mobiles in language learning is short message services - SMS. It can provide some of the essential ways to give quick attention to words (Nation, 2001). It is possible to provide a word with its L1 definition, synonym and an example or more in an SMS. Also it is possible to focus on a limited amount of information, since too much amount of information can be confusing and discouraging. Besides, they are encouraging to students, because they can study the lessons provided for them via SMS at any time and in any place that they prefer. Another optimal way of teaching vocabulary which is possible through SMS is spaced presentation which is more effective than massed presentation. According to cognitive psychologists when two presentations of a word are farther apart (spaced presentation), the learners' performance on memory test is significantly better than when the two presentations are close together (Thornton \& Houser, 2005).

In addition to other aspects of language learning, SMS has been extensively used to assist vocabulary learning. In an attempt to assess the effects of mobile phone on vocabulary learning, Thornton and Houser (2005) conducted three studies in a Japanese university. First they surveyed the students regarding their use of mobile phones. The result of the survey revealed that students used their mobiles frequently for sending SMS and emails than talking with their families and friends. Based on this finding, they conducted two counter balanced studies to compare the usefulness of delivering of vocabulary items via different mobile media. In one experiment, they compared sending some short mini lessons to students' emails on their mobiles with presenting them on paper. In another study, they compared sending lessons via SMS with presenting them on paper. In the second phase of this experiment they compared the effect of lessons' length on learning. They found no significant difference between long and short lessons. So they concluded that the effect of the frequency of the lessons was more important than the quantity of materials presented in a lesson. In another study by Thornton and Houser a phone sized website was developed to present students some idioms in Japanese and English along with some animations to illustrate them. All in all, these studies showed that mobile phones can potentially be useful in presenting foreign language materials to students.

In the same line, $\mathrm{Lu}$ (2008) used a counter-balanced design to investigate the usefulness of short message service (SMS) on 30 vocational high school students' vocabulary retention. In the first week of a two-week experiment, one group received 14 target words via SMS and the other group received the same material on paper. In the second week, the two groups changed their media; that is, the mobile group became paper group and the paper group became mobile group. At the end of each week, an immediate post-test, and three weeks later a delayed post-test was conducted. The results of the tests showed that both groups, regardless of the medium, had improved compared to the pre-test. But generally the mobile group's scores were significantly better than the paper group. It is worth mentioning that their scores diminished in the delayed post-test. This result underscores the effect of regular reading of vocabulary items and it suggests finding a way to investigate whether learners read frequently the lessons provided for them via SMS. A comparison of students' scores on mobile phone and paper showed that there was a positive relation between reading frequency and vocabulary gain. Also at the end of the experiment the participants were interviewed to find their attitude towards mobile-assisted language 
learning. The information gained by interview showed that generally students had positive attitudes towards mobile vocabulary learning and liked to continue learning vocabulary with the aid of mobile.

In a study conducted in Iran, Derakhshan and kaivanpanah (2011) provided evidence for the effectiveness of SMS on university students' vocabulary learning. During the experiment which lasted for seven weeks, the participants were taught fifteen to twenty words each session and were asked to work in groups to talk about the words. Then the experimental group's participants were told to send a sentence for each word taught in class to the researcher and to three of their classmates. The participants of the control group were asked to write sentences and bring them to the class. The practice of producing output helped to make input comprehensible for students. According to cognitive psychologists, having opportunities to produce language can make input more comprehensible and learners can construct their own understanding of the language (Warschauer \& Meskill, 2000).The result of the post-test showed that the experimental group had higher scores than the control group; that is, they outperformed the control group in vocabulary retention. Also a delayed post-test was administered two weeks later to compare the long-term effect of mobile vocabulary learning. It was found that there was no significant difference between the two groups. This result is in line with $\mathrm{Lu}(2008)$ in that the participants' scores diminished in the delayed post-test and none reached the significance level. However, in both studies, the experimental group had more vocabulary gain compared to the control group.

Since collocations do not receive enough attention in Iran, Motallebzadeh, beh-Afarin and Daliry Rad (2011) used short message service to help Iranian intermediate EFL learners to retain English collocations. During a five-week experiment one group of participants received seventy collocations along with their definitions and some example sentences via SMS and the other group received them on paper. In addition, both groups took two quizzes, one group via SMS and the other on paper. The result of the post-test showed that the participants in the experimental group outperformed those in the control group. Also their scores were significantly better in the post-test compared to the pre-test. Moreover, according to participants' responses to the attitude questionnaire the participants of the experimental group were asked to complete, they had positive attitudes towards learning collocations via SMS.

All previously mentioned researches investigated the effect of short message service feature of the mobile phones on vocabulary learning. In a different study, Baleghizadeh and Oladrostam (2010) used the recording feature of this technology to assess its effects on learners' grammatical accuracy. During six sessions of instruction they taught three grammatical categories to the participants. Then they chose topics related to those grammatical categories to be discussed in the class and asked the participants of the experimental group to use their mobile phones to record their voices while discussing those topics. They had to analyze their speech at home, find their grammatical mistakes and correct them for the next session. At the end of the experiment, a grammar test was administered to both groups the result of which showed that the mobile phone helped the experimental group to improve their grammatical accuracy as a result of which they performed better than the control group.

The literature shows that most researches have focused on teaching general vocabulary (e.g. Derakhshan \& Kaivanpanah 2011; Lu, 2008; Thornton \& Houser, 2005). Only very few studies have employed MALL to teach academic vocabulary items. Besides, the previously mentioned studies that employed SMS to enhance learners' vocabulary and collocation retention used SMS as a supplementary device to classroom vocabulary instruction (Derakhshan \& kaivanpanah, 2011). The studies done lasted for a short period of time and taught students very few numbers of collocation and words (Mottalebzadeh et al., 2011; Lu, 2008). The present study aimed to assess the effect of SMS vocabulary instruction on university students' academic vocabulary retention.

\section{Purpose of the Study}

The purpose of this study was to explore the difference between the long-term and short-term retention of words learnt via SMS. In addition it assessed the difference between the short and long-term retention of vocabulary items learnt via SMS and those learnt by using a dictionary. To this end, the following research questions were addressed in this study:

1) Is there any difference between university students' learning of academic vocabulary items provided via SMS and those learnt by using a dictionary?

2) Is there any difference between university students' retention of academic vocabulary items provided via SMS and those learnt by using a dictionary? 


\section{Methodology}

\subsection{Participants}

The participants of this study were 45 non-English major freshmen at Sharif University of technology in Tehran, Iran. One group was assigned as the experimental group $(\mathrm{N}=28)$ and the other as the control group $(\mathrm{N}=17)$. They were both male and female and were aged between 18- 21. They attended a general English course two times a week and were taught Active Skills for Reading 4 (Anderson, 2008) by the same instructor. As far as their English proficiency was concerned, they were at upper intermediate level and their use of English was mainly limited to the classroom

\subsection{Instruments}

One of the instruments used in this study was Academic Word List, AWL (Coxhead, 2000). This list is comprised of 10 sublists based on decreasing level of frequency. It totally contained 3000 academic words. The words to be sent via SMS were chosen from among the head words of the last 7 sublists which were considered suitable for the level of students. One of the reasons for choosing this list was that it highlighted the words that university students might encounter in an academic text, and it accounted for $10 \%$ of tokens in the academic corpus (Coxhead, 2000).

Another reason was the coverage of the academic words in participants' text book: Active Skills for reading 4 (Anderson, 2008). Academic vocabulary items constitute one of the four categories of words identified by Nation (2001). These words have communicative purposes and are essential for students when they take ESP courses. But the research showed that general English books have a low coverage of academic words. According to (Hsu, 2009), AWL accounts for $1.3 \%-6.54 \%$ of the total words in a GE textbook and it accounts for $4.63 \%$ of the total words in the participants' text book. While according to Hsu (2009) it should have $10 \%$ coverage for students to have a successful academic achievement. Hence, the AWL was chosen to be used in this study to compensate for the low coverage of academic words in the participants' textbook in the experimental and the control groups in order to help them improve their academic word knowledge.

Another instrument used in this study was a vocabulary test (appendix). It was composed of 40 multiple-choice items. To choose the vocabulary items, a list of 100 words taken from the AWL sublists ( 10 vocabularies from each sublist) was given to the whole students and they were asked to provide definitions for the words. Then from among the words that students had difficulty with, 40 vocabulary items were chosen and turned into multiple choice items. The multiple-choice tests were piloted with the similar students, and the reliability of the test calculated using Cronbach Alpha which was .89. At the end of the experiment the test was given to the participants as a post-test. For the delayed post-test the order of questions was changed in order to prevent the practice effect.

\subsection{Data Collection Procedures}

During the experiment, the participants in the experimental group received some vocabulary items selected from among almost the head words of the last 7 sublists of the academic word list (Coxhead, 2000). The reason why the last 7 sublists were used was the realization that the words in the first 3 sublists proved to be easy for the participants. During the 16 weeks of experiment, the participants of the experimental group received the word definitions (both Persian and English) as well as example sentences on a regular basis two times a week via SMS. In each attempt they received 10 words. Totally, 320 headwords were sent to the students. In addition, they were assessed each session by the instructor in class, to see how they had learned the vocabulary items. During the same period of time and within each session the participants of the control group were asked to look up 10 words in a dictionary and learn them. Like the experimental group, they were assessed by the instructor in class. Hence, the control group worked on the same number of words. It is worth mentioning that the words included in the post-test were worked on during the experiment and were made the subject of classroom assessment.

In order to assess the effects of instruction and assessment, both groups were administered a vocabulary test (immediate post-test) at the end of the experiment. Moreover, they took a delayed post-test 4 weeks after the experiment to see the long-term effect of mobile vocabulary learning on their vocabulary retention.

\section{Results and Discussion}

In order to answer the first research question dealing with the effect of SMS on students' vocabulary knowledge, first the mean and standard deviation of the post-test scores of the two groups were computed and their scores were compared by running an independent t-test. Table 1 shows the results of the post-test scores of the experimental and control groups. 
Table 1. Results of the Post- test Scores of the Experimental and Control Groups

\begin{tabular}{lcccc}
\hline Group & $\mathrm{N}$ & Mean & Std. Deviation & Std. Error Mean \\
\hline Experimental group & 28 & 25.17 & 5.74 & 1.08 \\
Control group & 17 & 22.64 & 5.18 & 1.25 \\
\hline
\end{tabular}

Table 2 shows the result of the independent t-test of the post-test scores of the two groups. The t-test result $(t=1.48, p=.42)$ shows that there was not any significant difference between the experimental and control groups in the post-test. Although there is not a significant difference between the two groups, the effect of text messaging on students' vocabulary retention cannot be overlooked and as shown in Table 1, the experimental group outperformed the control group in terms of their means.

Table 2. Independent Sample t-test Result for the Post-test Scores of the Experimental and Control groups

\begin{tabular}{|c|c|c|c|c|c|c|c|c|}
\hline \multicolumn{2}{|r|}{$\begin{array}{l}\text { Levene's Test } \\
\text { for Equality } \\
\text { of Variances }\end{array}$} & \multicolumn{7}{|c|}{ T-test for Equality of Means } \\
\hline \multirow[t]{2}{*}{$\mathrm{F}$} & sig. & $\mathrm{t}$ & $\mathrm{df}$ & $\operatorname{sig}(2-$ tailed $)$ & $\begin{array}{c}\text { mean } \\
\text { difference }\end{array}$ & $\begin{array}{l}\text { Std. Error } \\
\text { difference }\end{array}$ & $\begin{array}{r}95 \% \\
\text { interva } \\
\text { diffe }\end{array}$ & $\begin{array}{l}\text { nfidence } \\
\text { f the } \\
\text { ce }\end{array}$ \\
\hline & & & & & & & Lower & upper \\
\hline .65 & .42 & 1.48 & 43 & .14 & 2.52 & 1.70 & -.90 & 5.96 \\
\hline
\end{tabular}

This result is in line with Derakhshan and Kaivanpanah (2011) which showed that the difference between the experimental and control groups was not significant. The results are not in line with $\mathrm{Lu}$ (2008), which showed a significant difference between the two groups.

In order to assess the effect of SMS on participants' vocabulary retention (second research question) and to compare its short and long-term effect, first the mean and standard deviation of the post-test and delayed post-test scores of the experimental group were computed and then their scores were compared by running a dependent t-test. As seen in table 3, the experimental group had higher mean scores in the delayed post-test (26.78) compared to the post-test (25.17).

Table 3. Results of the Post and Delayed post- test Scores of the Experimental group

\begin{tabular}{llcc}
\hline Experimental group & $\mathrm{N}$ & Mean & Std.deviation \\
\hline Post-test & 28 & 25.17 & 5.74 \\
Delayed post-test & 28 & 26.78 & 5.43 \\
\end{tabular}

Table 4 shows the t-test result of the post-test and delayed post-test of the experimental group. As shown in the table, the experimental group performed significantly better in the delayed post-test than the post-test $(\mathrm{t}=-2.42$, $\mathrm{p}=.02)$.

Table 4. Paired sample t-test Result for the Post- test and Delayed Post- test Scores of the Experimental Group

\begin{tabular}{|c|c|c|c|c|c|c|c|}
\hline \multirow[t]{2}{*}{ Experimental } & \multicolumn{5}{|c|}{ Paired Differences } & \multirow{2}{*}{\multicolumn{2}{|c|}{$\mathrm{t} \quad \mathrm{df} \quad \operatorname{sig}(2$ tailed $)$}} \\
\hline & \multirow[t]{2}{*}{ Mean } & \multirow[t]{2}{*}{$\begin{array}{l}\text { std. } \\
\text { deviation }\end{array}$} & \multirow[t]{2}{*}{$\begin{array}{l}\text { std.error } \\
\text { mean }\end{array}$} & \multicolumn{2}{|c|}{$\begin{array}{l}95 \% \text { confidence } \\
\text { interval of the } \\
\text { difference }\end{array}$} & & \\
\hline & & & & Lower & upper & & \\
\hline $\begin{array}{l}\text { Post-test } \\
\text { delayed Post-test }\end{array}$ & -1.60 & 3.51 & .66 & -2.96 & -2.4 & $-2.42 \quad 27$ & .02 \\
\hline
\end{tabular}


Finally to explore the difference between the long-term retention of vocabularies learnt via SMS and those learnt by using a dictionary, an independent t-test was run on the mean scores of the delayed post-test of both groups. Table 5 shows the mean scores and standard deviation of the two groups in the delayed post-test. As the result shows, both groups have gained higher mean score in the delayed post-test compared to the post-test and the experimental group's means $(M=26.78)$ is higher than that of the control group $(M=22.09)$ in the delayed post-test.

Table 5. Results of the Delayed Post- test Scores of the Experimental and Control Groups

\begin{tabular}{lcccc}
\hline Group & $\mathrm{N}$ & Mean & Std.deviation & Std.error Mean \\
\hline Experimental & 28 & 26.78 & 6.96 & 1.48 \\
Control & 17 & 22.09 & 5.43 & 1.02 \\
\hline
\end{tabular}

The results of the t-test (table 6) show that there was a significant difference between the two groups' mean scores in the delayed post-test $(\mathrm{T}=-2.10, \mathrm{p}=.04)$.

Table 6. Independent t-test Result for the Delayed Post- test Scores of the Experimental and Control Groups

\begin{tabular}{|c|c|c|c|c|c|c|c|}
\hline $\begin{array}{r}\text { Le } \\
\mathrm{fc} \\
\text { of }\end{array}$ & $\begin{array}{l}\text { e's Test } \\
\text { quality } \\
\text { iances }\end{array}$ & & & & t-test for Equal & ty of Means & \\
\hline \multirow[t]{2}{*}{$\mathrm{F}$} & sig. & $\mathrm{t}$ & $\mathrm{df}$ & $\operatorname{sig}(2-$ tailed $)$ & $\begin{array}{l}\text { mean } \\
\text { difference }\end{array}$ & $\begin{array}{l}\text { Std. Error } \\
\text { difference }\end{array}$ & $\begin{array}{l}95 \% \text { confidence } \\
\text { interval of the difference }\end{array}$ \\
\hline & & & & & Lower upper & & \\
\hline 1.56 & .21 & -2.10 & 43 & .04 & $\begin{array}{ll}-4.69 & 1.75\end{array}$ & -7.21 & .17 \\
\hline
\end{tabular}

Interestingly, this result contradicts the results of previous studies which showed that both groups' scores decreased in the delayed post-test (Derakhshan \& Kaivanpanah, 2011; Lu, 2008), and none of the groups reached the significant level.

The findings of this study confirmed the usefulness of SMS on students' vocabulary learning and retention. The results of the present study showed that, in the short term, there was not any significant difference between learning vocabulary via SMS and by using a dictionary, however, learning vocabulary via SMS helped the participants in the experimental group to enhance their vocabulary knowledge in the post-test. But in the long term, vocabulary learning via SMS helped students to retain more vocabulary compared to those who used a dictionary for vocabulary learning.

This implies that using SMS helps to transfer vocabulary items into students' long-term memory. Since students are used to spending a lot of time using their mobiles, so having words on their mobiles might have encouraged them to review the vocabularies on a more regular basis. This can be proved by the fact that in the delayed post-test participants of the experimental group improved significantly and outperformed the participants of the control group.

Despite gaining more in the post-test, it appears that using a dictionary did not help the participants in the control group to transfer the learnt vocabulary items into their long-term memory. The reason might have been the fact that learning via a dictionary did not encourage the students to review the vocabulary items.

It can be concluded that in order for students to put efforts and time on studying new vocabulary items they should be responsible for their learning. Moreover, the method of teaching should have the capacity to encourage them to review and study the taught words on a more regular basis and take advantage of students' interest in using the device used for vocabulary learning (in this case mobile phone). Since as it was shown in this study, while both the experimental and control group were responsible for their learning, the experimental (MALL group) group retained more vocabulary in the delayed post-test than the control group (dictionary group). 


\section{Conclusion and Implications}

Vocabulary has a central role in language learning, and Language learners should know a large number of words to be successful in language learning or to have a successful communication in it. It also has a vital role in the 4 skills (speaking, reading, writing and listening). Hence this study aimed to investigate the effect of SMS on university students' vocabulary learning and retention. The findings approved the usefulness of SMS in this regard. The participants in the experimental group improved significantly in the immediate post-test and outperformed the control group in the delayed post- test.

Although being successful in confirming the effect of mobile vocabulary learning on vocabulary retention, this study had some limitations. The first limitation had to do with the number of characters allowed in an SMS. Due to this limitation, only a limited number of words could be sent in each attempt. Also the example sentences were chosen based on this limitation.

Another limitation of the present study was related to the number of participants in the experimental and control groups. As was mentioned the experimental group had more participants than the control group. This unequal number might have had an effect on the validity of the results obtained.

Despite this limitation, the results have some important implications among which we can refer to the usefulness of the incorporation of mobile learning into language courses. The findings can be useful for language teachers and language institutes. It offers them a readily available tool to help improving students' vocabulary knowledge. Since the students are used to using their mobiles and sending and receiving SMS, they can use it as a complementary device to face-to-face instruction and assessment. In this way they can move toward a learner-centered classroom and make students more responsible for their own learning.

The present study used mobile learning in a nonreciprocal way, but language teachers can use mobile learning in a reciprocal way. For instance, they can send some tests to students and ask them to send back the answers via SMS. Like teachers, students can also take advantage of mobile learning as a form of self-study. Using mobile to learn vocabulary can help them learn and retain large number of vocabulary items they are encountering inside and outside the classroom.

\section{References}

Baleghizadeh, S., \& Oladrostam, E. (2011). The Effect of Mobile Assisted Language Learning (MALL) on Grammatical Accuracy of EFL Students. MEXTESOL Journal, 34(2).

Coxhead, A. (2000). A New academic word list. TESOL QUARTERLY, 34(2), 213-238.

Derakhshan, A., \& Kaivanpanah, S. (2011). The Impact of text-messaging on EFL freshmen's vocabulary learning. EUROCALL, 39-47.

Geddes, S. J. (2004) Mobile learning in the 21st century: benefit to learners. Retrieved from $\mathrm{http} / /$ knowledgetree.flexiblelearning.net.au/edition06/download/geddes.

Hsu, W. (2009). College English Textbooks for general English purposes: a corpus-based analysis of lexical coverage. Electronic Journal of Foreign Language Teaching, 6(1), 42-62.

Laufer, B. (1998). The Development of passive and active vocabulary in a second language: Same or different? Applied Linguistics, 19(2), 255-271.

Lu, M. (2008). Effectiveness of vocabulary learning via mobile phone. Journal of Computer Assisted Learning, 24(6), 515-525. http://dx.doi.org/10.1093/applin/19.2.255

Motallebzadeh, K., Beh-Afarin, R., \& Daliry Rad, S. (2011). The Effect of short message service on the retention of collocations among Iranian lower intermediate EFL learners. Theory and Practice in Language Studies, 1(11), 1514-1520. http://dx.doi.org/10.4304/tpls.1.11.1514-1520

Nation, I. S. P. (2001). Learning vocabulary in another language. Cambridge: Cambridge University Press

Nation, I. S. P. (2006). How large a vocabulary is needed for reading and listening? The Canadian Modern Language review, 63(1).

Nation, P. (2005). Teaching Vocabulary. Asian EFL Journal, 7(3), 47- 54.

O'Malley, C., Vavoula, G., Glew, J., Taylor, J., Sharples, M., \& Lefrere, P. (2003). Guidelines for learning /teaching/ tutoring in a mobile environment. Mobile project deliverable. Retrieved from http://www.mobilearn.org/download/results/guidelines.pdf 
Prensky M. (2005). What can you learn from a cell phone? Almost anything! The Innovate Gateway 1 (June/July). Retrieved from http://www.innovateonline. Info/index.php?view=article\&id=83 (last accessed 7 June 2006).

Salaberry, M. R. (2001). The use of technology for second language learning and teaching: A retrospective. Modern Language Journal, 85, 39-56. http://dx.doi.org/10.1111/0026-7902.00096

Thornton, P., \& Houser, C. (2005). Using mobile phones in English education in Japan. Journal of Computer Assisted Learning, 21(3), 217-228. http://dx.doi.org/10.1111/j.1365-2729.2005.00129.x

Warschauer, M., \& Meskill, C. (2000). Technology and second language teaching. In J. W. Rosenthall (Ed.), Handbook of undergraduate second language education (pp. 303-318). NJ, Mahwah: Lawrence Erlbaum.

\section{Appendix}

\section{Word meaning}

\section{A. Read the sentences and choose the best answer.}

1. Visitors to a new country are encouraged to with the local people to learn more about their culture.

a. restrain

b. interact

c. cope

2. In unlocking the secrets of DNA, scientists have opened up new areas of conflict between scientific progress and ethics.

a. armed

b. constant

c. potential

3. Conversation analysts have found that women tend to be competitive.

a. contributor

b. dominant

c. cooperative

4. Although the people's beliefs about crime.

a. criteria

b. validity

c. stability

5. The meat of a young chicken is tender and juicy, but it may lack the flavor of poultry.

a. mature

b. saturated

c. organic

6. It is important that the Food and Drug Administration in conversations, while men tend to be differences can influence the effectiveness of new drugs.

a. integrate

b. undertake

c. reinforce

7. The ......... of malaria has been rising in recent years.

a. incidence

b. investigation

c. inspection

8. It is important to keep food in the refrigerator at $41^{\circ} \mathrm{F}\left(5^{\circ} \mathrm{C}\right)$ or colder to bacterial growth. 

a. eliminate
b. inhibit
c. decline

9. Increased worldwide usage of automobiles is a/an consequence of the economic growth of developing countries.
a. ultimate
b. sustainable
c. inevitable

10. Sparkling water is often served as a to fine food because it can aid digestion.
a. complement
b. substance
c. supply

11. Mothers Against Drunk Drivers (MADD) has urged the U.S. Congress to impose stiff penalties on drunk drivers.
a. issue
b. credit
c. draft

12. There is unlikely to be peace in Northern Ireland until republicans and unionists reach a legislation that would parliamentary disarmament.
a. protocol
b. consent
c. target

13. The essential of family life are similar worldwide despite differing family structures.
a. principles
b. preliminaries
c. dynamics

14. The rising cost of living and a disappointing stock market may the trend toward early retirement.
a. reverse
b. follow
c. invoke

B. Read the sentences and choose the word or phrase that best matches the meaning of the target word. Use context clues to determine the correct meaning.

15. Having a college education increases a person's prospect of finding a good job.

a. a difficult choice

b. several things working together

c. the chance of something happening

16. It is difficult to conceive of the vastness of the universe.

a. imagine what something is like

b. control something completely

c. change something for the better

17. Upon start-up, computers automatically do an internal check of the integrity of all of their components.

a. good condition; soundness

b. bad or faulty condition 
c. lack of unity

18. Alexander Fleming deduced that the spores of a mold called penicillin had disease-preventing qualities when he observed that it prevented the growth of germs.

a. took responsibility for something

b. used information to make a judgment about something

c. gave a reason for something

19. Saturn is not perfectly spherical in shape; rather, it is quite flat as its pole.

a. smooth

b. rough

c. round

20. Gold, sugar, and petroleum are some of the commodities commonly traded on the open market.

a. something that you work hard to attain

b. a product that is bought and sold

c. the best example of something

21. Her aggregate income from stocks, bonds, and property rental was over $\$ 4,000$ per month.

a. amazing

b. large

c. total

22. Most modern coal-fired boilers utilize coal that has been ground down to fine particle sizes.

a. use something for a particular purpose

b. refuse to do something

c. abandon something or someone

23. Courses that prepare students for careers in the sciences normally incorporate a lot of mathematics.

a. develop something gradually

b. include something as a part of a plan or system

c. give something more energy

24. The companies' recruitment procedures have undergone a number of changes that will be tested at the university careers fair.

a. created something that did not exist before

b. happened or been done to someone or something

c. given strength or support to someone or something

C. Read each target word and the list below. One word in each list is NOT a synonym for the target word. Cross it out.

\section{5. infrastructure}

a. organization b. legislation c. system

\section{6. arbitrary}
a. random
b. deliberate
c. unfair

\section{7. highlight}
a. top off
b. stress
c. underline

\section{8. extract}
a. supplement
b. take out
c. dig out

29. subsidy
a. funding
b. levy
c. grant 


\section{0. constraint}
a. confinement
b. subordinate
c. restraint

\section{Collocation}

D. Match each target word in the box with the group of words that regularly occur with it. In all cases, the target word comes before the word in the list. One of the given words is extra.

statistical disposable undertake

precise pursue

\section{Word families}

\begin{tabular}{|c|c|c|c|}
\hline $\begin{array}{l}\text { 31............ } \\
\text { objectives } \\
\text { careers } \\
\text { interests } \\
\text { policies }\end{array}$ & $\begin{array}{l}\text { 32. ....... } \\
\ldots . . \\
\text { analysis } \\
\text { significanc } \\
\text { e } \\
\text { techniques } \\
\text { tables }\end{array}$ & $\begin{array}{l}\text { 33............ } \\
\text { a challenge } \\
\text { a journey } \\
\text { a } \\
\text { responsibility } \\
\text { training }\end{array}$ & $\begin{array}{l}\text { 34. .......... } \\
\text { nature } \\
\text { moment } \\
\text { details } \\
\text { location }\end{array}$ \\
\hline
\end{tabular}

E. Complete each sentence using the words in the box. Be sure to use the correct form of each word.

\begin{tabular}{|l|l|l|l|l|l|}
\hline coherence & corporate & access & submit & eliminate & distort \\
\hline
\end{tabular}

35. The negotiators hoped to agree to a treaty in time for to the current United Nations General Assembly.

36. Protestors against globalization believe that international are major contributors to the destruction of local cultures.

37. The speaker spoke persuasively and about the dangers of global warming.

38. A key cost-saving strategy for companies is the of waste.

39. After the man had a stroke, his voice was so. that we couldn't figure out what he was trying to say.

40. Companies must be prepared to provide a workstation that is wheelchair to any staff member who may need one. 